\title{
Corrosion of Longquan celadons in the marine environment: study on the celadons from the Dalian Island shipwreck of the Yuan Dynasty
}

Yan $\mathrm{He}^{1,2,3,4}$, Weidong $\mathrm{Li}^{1,2,3,4^{*}}$, Jianan $\mathrm{Li}^{5}$, Changsong $\mathrm{Xu}^{1,2,3,4}$ and Xiaoke $\mathrm{Lu}^{1,2,3,4}$

\begin{abstract}
The Dalian (大练) Island shipwreck of the Yuan Dynasty (1271-1368 CE) was located in the sea area of Pingtan (平潭 ), Fujian (福建) Province, China. A total of 603 Longquan (龙泉) celadon wares were excavated, some of which have been severely corroded. In this study, two celadon specimens with severe corrosion were selected to investigate the corrosion mechanism in the marine environment. Optical microscopy (OM), scanning electron microscopy equipped with energy dispersive X-ray spectrometry (SEM-EDS), X-ray diffraction analysis (XRD), Micro-Raman spectroscopy, and thermal expansion analysis were applied to analyze the microstructure of the glaze, corrosion morphology, and composition of corrosion products, and the corrosion mechanism was discussed in depth. The results showed that these two celadon wares are opaque matt glaze, in which the anorthite crystallization-phase separation structure with low chemical stability was found, which was more likely to be corroded. There are three possible stages in the corrosion process of the glaze. The first stage is mainly the long-term cation exchange reaction. Then, because of the corrosion of the $\mathrm{CaO}$-rich droplet phase and the crystal-glass phase interface layer, the porous structure and many microcracks may be formed, promoting the corrosion process. Finally, many corrosion craters, caused by the shedding of anorthite crystals, may appear on the glaze surface. The quintinite group minerals in the glaze were probably formed during the corrosion process, which may be related to the marine buried environment and the corrosion of the glaze. This study discussed the influencing factors of the corrosion process of celadon wares in the marine environment from the perspective of microstructure for the first time, which is of great significance to the study of the corrosion mechanism of ancient ceramics.
\end{abstract}

Keywords: Celadon glaze, Corrosion mechanism, Marine environment, Microstructure, Shipwreck, Heritage conservation

\section{Introduction}

Chinese porcelain was exported overseas as an important commodity as early as the Tang Dynasty (618-907 CE) and was loved by people all over the world in history [1]. However, in the history of the East-West porcelain trade

\footnotetext{
*Correspondence: liwd@mail.sic.ac.cn

1 Shanghai Institute of Ceramics, Chinese Academy of Sciences, Shanghai 201899, China

Full list of author information is available at the end of the article
}

for thousands of years, many merchant ships loaded with Chinese porcelain wares, unfortunately, sank into the sea due to natural and man-made disasters and were buried by marine sediment $[2,3]$. These ceramics have experienced hundreds or even thousands of years of alteration process caused by various physical, chemical, and biological factors in the marine environment. Various corrosion phenomena have seriously affected the beauty of these precious cultural relics, and have brought severe challenges to the treatment and preservation after the
Springer Open

(c) The Author(s) 2021. Open Access This article is licensed under a Creative Commons Attribution 4.0 International License, which permits use, sharing, adaptation, distribution and reproduction in any medium or format, as long as you give appropriate credit to the original author(s) and the source, provide a link to the Creative Commons licence, and indicate if changes were made. The images or other third party material in this article are included in the article's Creative Commons licence, unless indicated otherwise in a credit line to the material. If material is not included in the article's Creative Commons licence and your intended use is not permitted by statutory regulation or exceeds the permitted use, you will need to obtain permission directly from the copyright holder. To view a copy of this licence, visit http://creativecommons.org/licenses/by/4.0/. The Creative Commons Public Domain Dedication waiver (http://creativeco mmons.org/publicdomain/zero/1.0/) applies to the data made available in this article, unless otherwise stated in a credit line to the data. 
excavation. At present, more than $90 \%$ of the cultural relics excavated by underwater archaeology in China were ceramic wares [4], but there is still a lack of in-depth scientific cognition of the damage to the ceramics in the marine environment, and a systematic protection scheme has not yet been formed. This had become an important issue that urgently needs to be resolved in the protection of cultural relics excavated underwater.

At present, ion exchange $\left(\mathrm{H}^{+} /\right.$alkali and alkaline earth metal ions), $\mathrm{Si}-\mathrm{O}-\mathrm{Si}$ network hydrolysis, and the resulting microcrack and the loss of protonation of the network were considered to be the important causes of glass corrosion in the seawater [5-8]. In the protection field of cultural relics, some researchers studied the effect of soluble salt on ceramics and the method of desalination [9-13]. There have also been some preliminary studies on the formation and removal of different types of concretion and contaminant [14-16], and some researchers have discussed the secondary damage of ceramics in the process of conservation and treatment after excavation [17, 18]. Although the scientific cognition of ceramics excavated underwater has made considerable progress, the research on the corrosion of ancient ceramics in the marine environment is still not enough, especially the porcelains that are generally considered to have good corrosion resistance. The corrosion mechanism of the celadon glaze in the natural environment has not yet reached a consensus, and there is a lack of a comprehensive understanding of the various factors affecting the corrosion process, which is obviously not conducive to the subsequent treatment and protection work.

In this study, the ancient celadon wares from the Dalian Island shipwreck of the Yuan Dynasty were selected as a typical case, aiming to explore the corrosion process of celadons in the marine environment and its influencing factors. The shipwreck is located in the coastal waters of Pingtan, Fujian Province, China (Fig. 1), with a water depth of $15-18 \mathrm{~m}$. The underwater archaeological excavations of the shipwreck were carried out in 2007. A total of 603 celadon wares were excavated from the shipwreck site, all of which were exported celadons from Longquan kiln [19]. In this paper, the corrosion of the ancient celadons was discussed from the perspectives of chemical composition and microstructure, which is very important for the protection of cultural relics excavated from the marine environment.

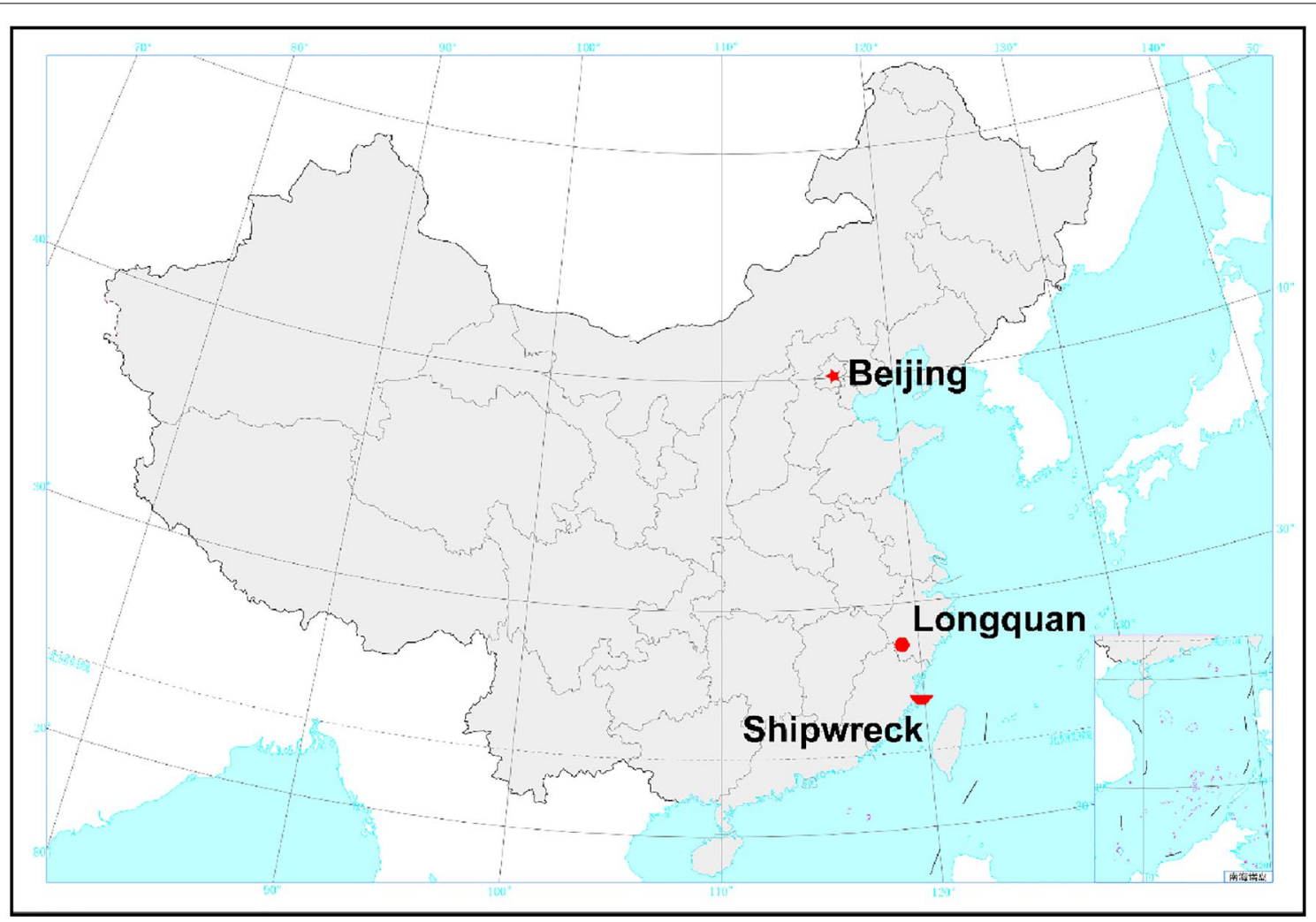

Fig. 1 Schematic diagram of the geographical location of the Dalian Island shipwreck of the Yuan Dynasty 


\section{Materials and methods}

\section{Samples}

In order to systematically study the corrosion of the celadon wares from the Dalian Island shipwreck, 11 pieces of celadon shards with different corrosion degrees, provided by Fujian Museum, were selected as the research object. These shards have been immersed in deionized water for desalination in the museum before they were provided to us. The desalination time is 5 weeks.

The samples were numbered from 01 to 11 and the detailed information can be seen in Table S1 and S2 in the Additional file 1. After observation and analysis, two severely corroded fragments (Nos. 08 and 09) among them were found to have significant representativeness, so they were chosen as the experimental samples in this paper for the key analysis. The photos and appearance descriptions are listed in Table 1.

The characteristic parts of the samples were cut from the shards and then cleaned by deionized water and ethanol in an ultrasonic cleaner (2 times for deionized water, 1 time for ethanol, 15 min each time). After that, all samples were dried in a drying oven at $110{ }^{\circ} \mathrm{C}$ for $3 \mathrm{~h}$.

\section{Methods}

X-ray diffraction (Bruker D8 DISCOVER) using $\mathrm{Cu} \mathrm{K \alpha}$ radiation was applied to investigate the phase components of the glaze surface. The voltage is $40 \mathrm{kV}$, the current is $40 \mathrm{~mA}$, the scan rate is $5\left(^{\circ}\right) / \mathrm{min}$, and the angle range is $10^{\circ}-80^{\circ}$.

Micro-Raman spectroscopy (Horiba XploRA one $532 \mathrm{~nm}$ ) was used to examine the crystals and glass phase in the glaze. The wavenumber calibration of the peak position was at $a \times 50$ objective with a piece of crystal silicon. A confocal microscope (Olympus BX41) was employed to focus the laser beam on the test areas with $\times 10$ and $\times 50$ objectives. The baseline was subtracted using the LABSPEC software. Then, the Raman spectra of glassy phase were de-convoluted and curvefitted with Gaussian functions using the Origin software $[20,21]$.

The macroscale morphology of the glaze surfaces and polished cross-sections were observed with an optical microscope (Keyence VHX-2000). The micromorphology and micro-area chemical compositions of glaze surface and polished cross-section of samples were characterized using field emission scanning electron microscope (FEI Magellan400) equipped with EDS.

The firing temperature of the bodies was examined by dilatometer (NETZSCH DIL $402 \mathrm{C}$ ). To prepare the test sample for dilatometer, the glaze layer was ground off first, and the body was made into a strip of $5 \mathrm{~mm} \times 5 \mathrm{~mm} \times 25 \mathrm{~mm}$. The heating rate was $5^{\circ} \mathrm{C} / \mathrm{min}$ and the approximate value of the firing temperature of the sample was obtained according to the inflection point in the thermal expansion curve [22, 23].

\section{Results}

The microstructure of the original glaze

Figure $2 \mathrm{a}$ is the OM image of the glaze surface of No. 08. The glaze is almost opaque and the color is uneven. It can be found that many long rod-like crystals are spread on the glaze surface with a length of up to $100 \mu \mathrm{m}$ and a width of about $5 \mu \mathrm{m}$. A cluster of radially interwoven crystals is shown in Fig. 2b. The EDS analysis results show that the long rod-like crystals have a high content of $\mathrm{MgO}$ and $\mathrm{CaO}$ (Table 2), which are

Table 1 The detailed information of the celadon samples

\begin{tabular}{|c|c|c|}
\hline Sample No & Digital photo & Appearance and state of conservation \\
\hline 08 & & Matt glaze, rough surface, slightly corroded \\
\hline 09 & & Matt glaze, severely corroded, yellow substances \\
\hline
\end{tabular}



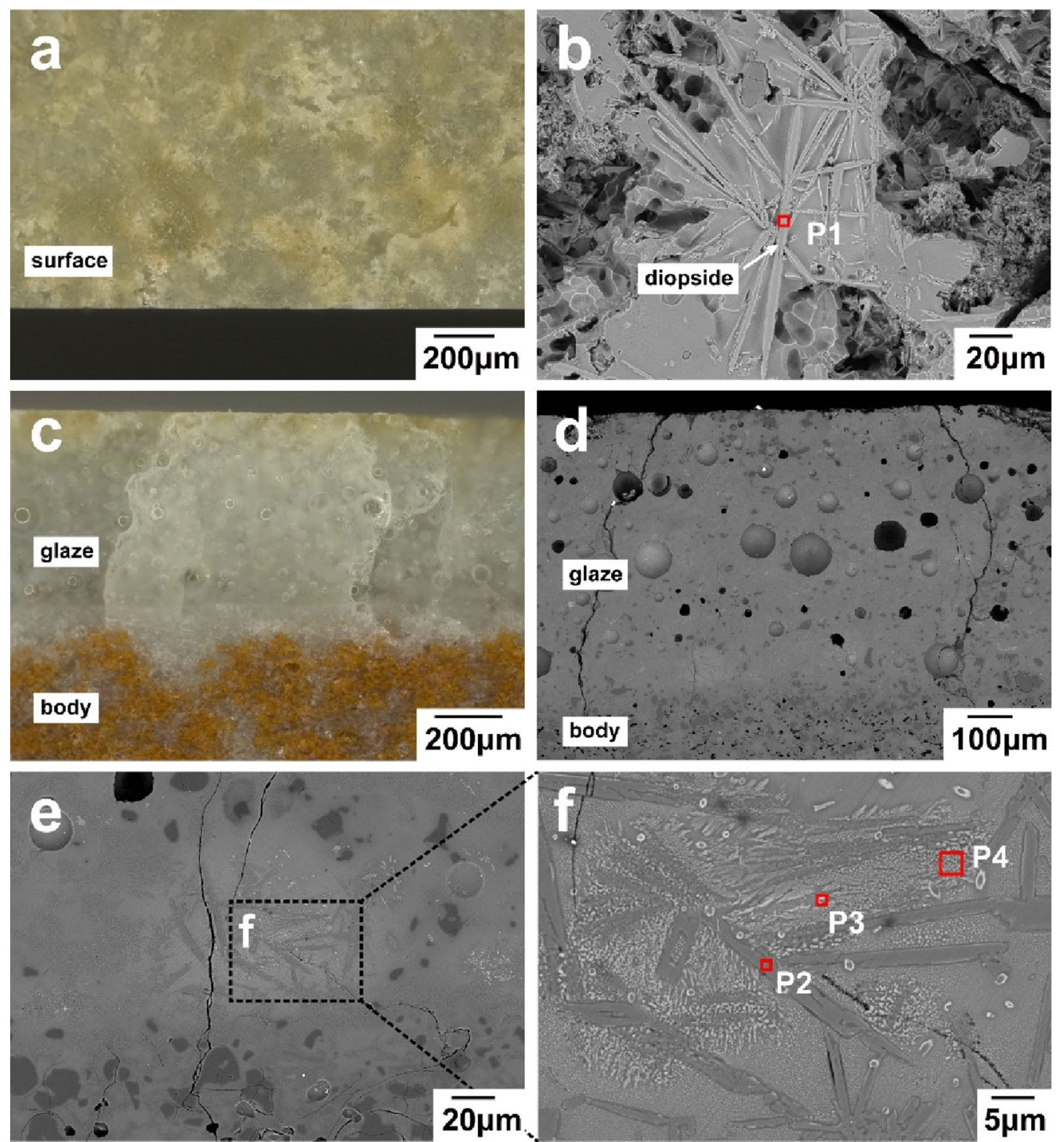

Fig. 2 OM and SEM images of sample No. 08, a glaze surface; $\mathbf{b}$ a cluster of radially interwoven long rod-like diopside crystals on the glaze surface; $\mathbf{c}$ and $\mathbf{d}$ the polished cross-section; $\mathbf{e}$ and $\mathbf{f}$ the column-like anorthite crystals near glaze-body interface; The marked positions (P1-P4) were examined by EDS and the results were listed in Table 2

Table 2 Chemical compositions of the marked positions in Fig. $2 b$ and $f$

\begin{tabular}{|c|c|c|c|c|c|c|c|c|c|c|c|c|}
\hline Position No. & Ratio & $\mathrm{Na}_{2} \mathrm{O}$ & $\mathrm{MgO}$ & $\mathrm{Al}_{2} \mathrm{O}_{3}$ & $\mathrm{SiO}_{2}$ & $\mathrm{~K}_{2} \mathrm{O}$ & $\mathrm{CaO}$ & $\mathrm{TiO}_{2}$ & $\mathrm{Fe}_{2} \mathrm{O}_{3}$ & $\mathrm{MnO}$ & $\mathrm{P}_{2} \mathrm{O}_{5}$ & Possible phase \\
\hline \multirow[t]{2}{*}{ P1 } & wt $\%$ & & 15.45 & 3.84 & 51.42 & & 28.49 & & 0.79 & & & Diopside \\
\hline & mol\% & & 21.55 & 2.10 & 47.74 & & 28.34 & & 0.28 & & & \\
\hline \multirow[t]{2}{*}{ P2 } & wt $\%$ & 1.09 & 0.86 & 26.12 & 55.31 & 2.21 & 13.49 & & 0.91 & & & Anorthite \\
\hline & mol\% & 1.18 & 1.45 & 17.24 & 61.97 & 1.58 & 16.19 & & 0.38 & & & \\
\hline \multirow[t]{2}{*}{ P3 } & $w t \%$ & 0.42 & 0.76 & 7.83 & 33.93 & 3.56 & 30.31 & & 1.73 & 0.70 & 20.76 & Calcium phosphate \\
\hline & mol\% & 0.48 & 1.35 & 5.44 & 39.98 & 2.68 & 38.26 & & 0.77 & 0.70 & 10.35 & \\
\hline \multirow[t]{2}{*}{ P4 } & wt $\%$ & 0.30 & 5.15 & 10.83 & 60.30 & 5.07 & 9.23 & 0.46 & 5.11 & 2.25 & 1.30 & Glass \\
\hline & mol\% & 0.31 & 8.36 & 6.89 & 65.15 & 3.49 & 10.68 & 0.37 & 2.07 & 2.06 & 0.59 & \\
\hline
\end{tabular}


likely to be diopside crystals based on the stoichiometric ratio, and some $\mathrm{Mg}^{2+}$ and $\mathrm{Si}^{4+}$ ions in the crystal are partially replaced by $\mathrm{Al}^{3+}$ ions and a few $\mathrm{Fe}^{3+}$ ions. The Raman spectrum of the long rod-like crystal is in good agreement with the reference spectrum of the diopside crystal (Fig. 3a), which further confirms its existence. Besides, the broad peaks around $500 \mathrm{~cm}^{-1}$, $767 \mathrm{~cm}^{-1}$, and $1000 \mathrm{~cm}^{-1}$ are the characteristics of the silicate glass.

It can be seen in the OM image of the polished crosssection of No. 08 (Fig. 2c) that many cracks penetrate the glaze layer. The SEM image shows (Fig. 2d) that many unmelted quartz grains (the Raman spectrum is shown in Fig. 3b) and bubbles with different sizes are densely distributed in the glaze. A large number of column-like anorthite and crystals with high $\mathrm{P}_{2} \mathrm{O}_{5}$ content are distributed in the glaze (Fig. 2e and f), the Raman spectrum of the column-like crystals is shown in Fig. 3c, and the EDS analysis results are listed in Table 2. The presence of phosphorus-containing crystals may be related to the use of botanic ash, a glaze flux widely used in ancient China [24, 25].

The glaze layer of sample No. 09 has been corroded severely, and the remaining opaque glaze was loose and porous. Figure $4 \mathrm{a}$ is the OM image of the glaze surface of No. 09. There are plenty of yellow substances on the surface, which are mixed with the remaining glaze. The SEM image of the glaze surface (Fig. 4b) shows that the remaining glaze on the left is already full of interconnected holes. Under further magnification (Fig. 4c), it is found that there are many long rod-like diopside crystals and some quartz grains in the glaze (see Table 3 for the EDS analysis results), which has a certain similarity with sample No. 08 .

\section{The micromorphology of the corroded glaze of No.08}

There are many corrosion craters on the glaze surface, and the edges of the craters are opaque white. The cracks and corrosion craters on the glaze surface of No. 08 can be observed more clearly from the SEM image (Fig. 5a). There are a large number of craters with different depths near the crystals. The craters near the cracks on the glaze surface are particularly prominent (Fig. 5b), and they are connected to each other in a large area. The magnified SEM images of the craters (Fig. $5 \mathrm{c}$ and d) show that the column-like anorthite crystals (Table 4) in the glaze are exposed outside, and the phase-separated droplets in the nearby glass phase were corroded into a porous structure. At the edge of the crater near glaze surface, it can be found that a large number of column-like crystals with lower contrast and rhomboid crystals with higher contrast (Fig. 5e), which may be anorthite crystals and diopside crystals according to the morphology and previous EDS analysis results. There are obvious interstices between the column-like anorthite crystals and the nearby glass phase. The magnified SEM images (Fig. 5f) showed that there is a sub-micron phase-separation structure in the glass phase near the anorthite crystals, and the original phase-separated droplets with higher contrast have been corroded, forming a porous structure. The phase-separated droplets at the interface between the anorthite crystals and glass phase were also corroded by seawater, forming interstices.

To characterize the alteration of the glass phase, the Raman spectra of the glass phase were recorded at the surface craters (corroded region) and cross-section (original glaze), and the representative results were shown in the Fig. 6a and b.Two main broad peaks at $\sim 480 \mathrm{~cm}^{-1}$ and $\sim 1000 \mathrm{~cm}^{-1}$ originated from the $\mathrm{SiO}_{4}$
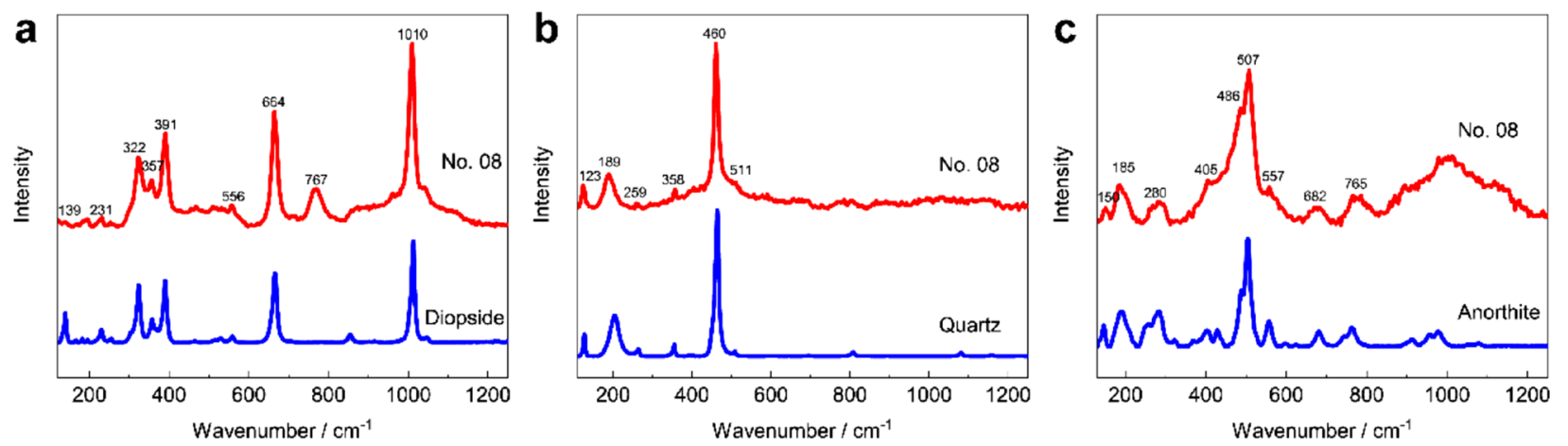

Fig. 3 Raman spectra recorded in the crystalline zone of the glaze of sample No. 08, a long rod-like diopside crystals and glass phase on the glaze surface; b quartz grains; c column-like crystals and glass phase, and for comparison, the reference spectra of diopside (RRUFF ID: R040009) [56], quartz (RRUFF ID: R040031) [57], and anorthite (RRUFF ID: R040059) [58] are cited 

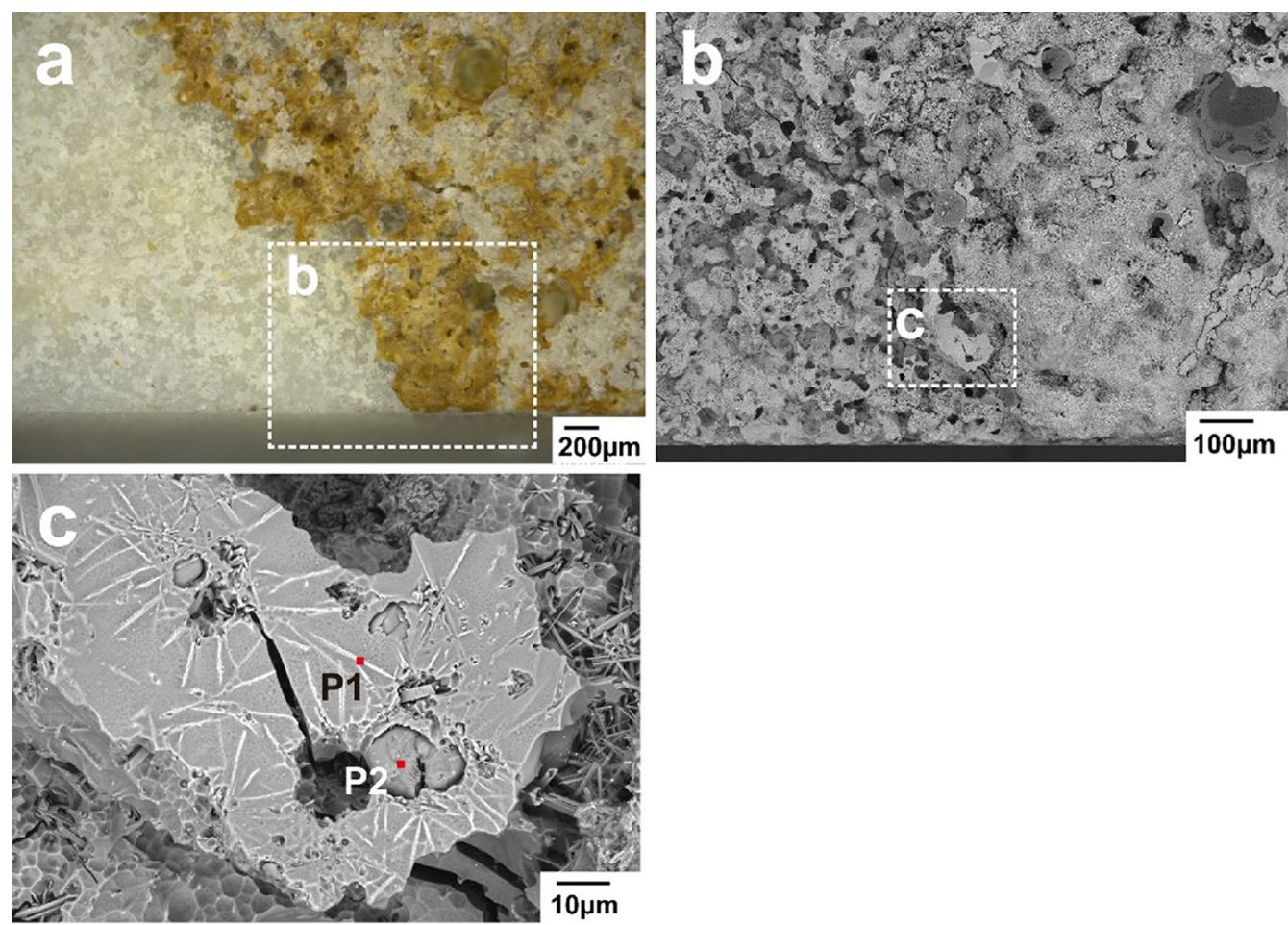

Fig. 4 OM and SEM images of sample No. 09, $\mathbf{a}$ and $\mathbf{b}$ corroded glaze surface; $\mathbf{c}$ the rectangle region in (b): the remaining opaque glaze. The marked positions (P1 and P2) were examined by EDS and the results were listed in Table 3

Table 3 Chemical compositions of the marked positions in Fig. 4C

\begin{tabular}{|c|c|c|c|c|c|c|c|c|}
\hline Position No & Ratio & $\mathrm{MgO}$ & $\mathrm{Al}_{2} \mathrm{O}_{3}$ & $\mathrm{SiO}_{2}$ & $\mathrm{~K}_{2} \mathrm{O}$ & $\mathrm{CaO}$ & $\mathrm{Fe}_{2} \mathrm{O}_{3}$ & Possible phase \\
\hline \multirow[t]{2}{*}{ P1 } & wt $\%$ & 11.79 & 7.68 & 51.43 & 1.46 & 26.21 & 1.43 & Diopside \\
\hline & mol\% & 17.16 & 4.38 & 49.83 & 0.90 & 27.20 & 0.52 & \\
\hline \multirow[t]{2}{*}{ P2 } & $w t \%$ & & 5.40 & 91.43 & 3.17 & & & Quartz \\
\hline & mol\% & & 3.29 & 94.61 & 2.09 & & & \\
\hline
\end{tabular}

tetrahedron bending and stretching modes, respectively [21]. Four typical components $\left(\mathrm{Q}^{0}, \mathrm{Q}^{1}, \mathrm{Q}^{2}\right.$, and $\mathrm{Q}^{3-4}$ ) could be extracted from the stretching envelopes, according to the description with a set of more or less connected $\mathrm{SiO}_{4}$ tetrahedron [21], and their positions were listed in Table 5 . The area ratios of bending peak over stretching peak $\left(\mathrm{A}_{500} / \mathrm{A}_{1000}\right)$ were calculated to analyze the polymerization degree of the glaze [20]. The results (Table 5) showed that $\mathrm{A}_{500} /$ $A_{1000}$ ratio of the surface crater is lower than that of the cross-section, indicating a different polymerization degree. And the relatively lower $\mathrm{A}_{500} / \mathrm{A}_{1000}$ ratio $(\sim 1.5)$ may also correspond to the lower firing temperature $[20,26]$. The wavenumber downshift of the
$\mathrm{Q}^{3-4}$ component of the surface crater (Table 5) may be related to a lengthening of the $\mathrm{Si}-\mathrm{O}$ bond because of the interaction of the oxygen atoms with newly inserted protonic species [6]. The area ratios of three components $\left(\mathrm{Q}^{1}, \mathrm{Q}^{2}\right.$, and $\left.\mathrm{Q}^{3-4}\right)$ over stretching peak subtracting $\mathrm{Q}^{0}$ (Table 5) were also calculated to analyze the alteration of each component [27]. Figure $6 \mathrm{c}$ shows that $\mathrm{A}_{3-4} /\left(\mathrm{A}_{1000}-\mathrm{A}_{0}\right)$ ratios were larger than 0.45 , indicating the sheet-like region and tectosilicates $\left(\mathrm{Q}^{3-4}\right)$ mainly preserve the main connected framework [20]. The $A_{1} /\left(A_{1000}-A_{0}\right)$ ratio of surface crater increased a lot while $A_{2} /\left(A_{1000}-A_{0}\right)$ and $A_{3-4} /\left(A_{1000}-A_{0}\right)$ decreased compared to that of the cross-section, 

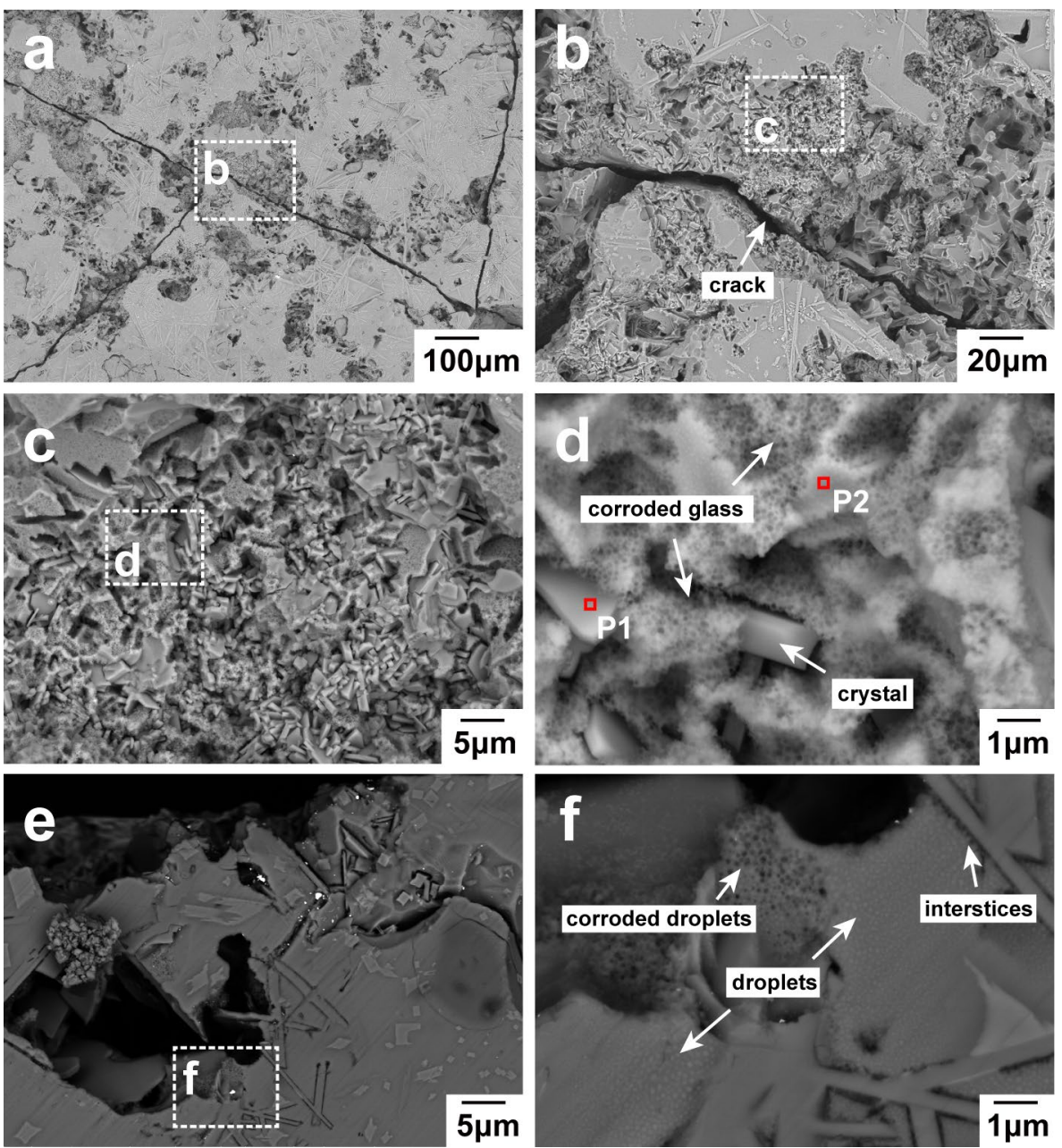

Fig. 5 OM and SEM images of the corroded region of No. 08, a glaze surface; $\mathbf{b}$ and $\mathbf{c}$ the interconnected craters near a crack; $\mathbf{d}$ corroded phase-separation structure and short column-like anorthite crystals in a crater; e a crater near glaze surface, observed from cross-section; f the rectangle region in (e): column-like crystals and corroded phase-separation structure. The marked positions (P1 and P2) were examined by EDS and the results were listed in Table 4

Table 4 Chemical compositions of the marked positions in Fig. $5 d$

\begin{tabular}{lllllllllll}
\hline Position No. & Ratio & $\mathbf{N a}_{\mathbf{2}} \mathbf{O}$ & $\mathbf{M g O}$ & $\mathbf{A l}_{\mathbf{2}} \mathbf{O}_{\mathbf{3}}$ & $\mathbf{S i O}_{\mathbf{2}}$ & $\mathbf{K}_{\mathbf{2}} \mathbf{O}$ & $\mathbf{C a O}$ & $\mathrm{Fe}_{2} \mathbf{O}_{\mathbf{3}}$ & $\mathbf{P}_{\mathbf{2}} \mathbf{O}_{\mathbf{5}}$ & Possible phase \\
\hline P1 & wt $\%$ & 1.51 & 2.09 & 26.91 & 49.48 & 1.47 & 18.53 & & & \\
& mol\% & 1.61 & 3.46 & 17.48 & 54.54 & 1.03 & 21.88 & & Anorthite \\
P2 & wt\% & 0.90 & 2.78 & 12.88 & 65.02 & 4.77 & 12.91 & 0.36 & 0.38 & Glass \\
& mol\% & 0.92 & 4.40 & 8.00 & 68.57 & 3.21 & 14.58 & 0.14 & 0.17 & \\
\hline
\end{tabular}

indicating the breaking of $\mathrm{Si}-\mathrm{O}$ bonds associated with corrosion $[6,27]$. Therefore, the integrity of the glass network seemed to be altered after seawater corrosion.

\section{The micromorphology of the corroded glaze of No.09}

To further study the corrosion process of sample No. 09, an area where the glaze remained more was selected for in-depth characterization. The OM image of the polished cross-section of this area is shown in Fig. 7a. The body of the area has a concave face, the glaze layer is obviously thicker than other areas, and the alteration of the glaze layer in the concave area is relatively slight. In the SEM image (Fig. 7b), a crack penetrating from the glaze surface to the glaze-body interface can be observed. There 

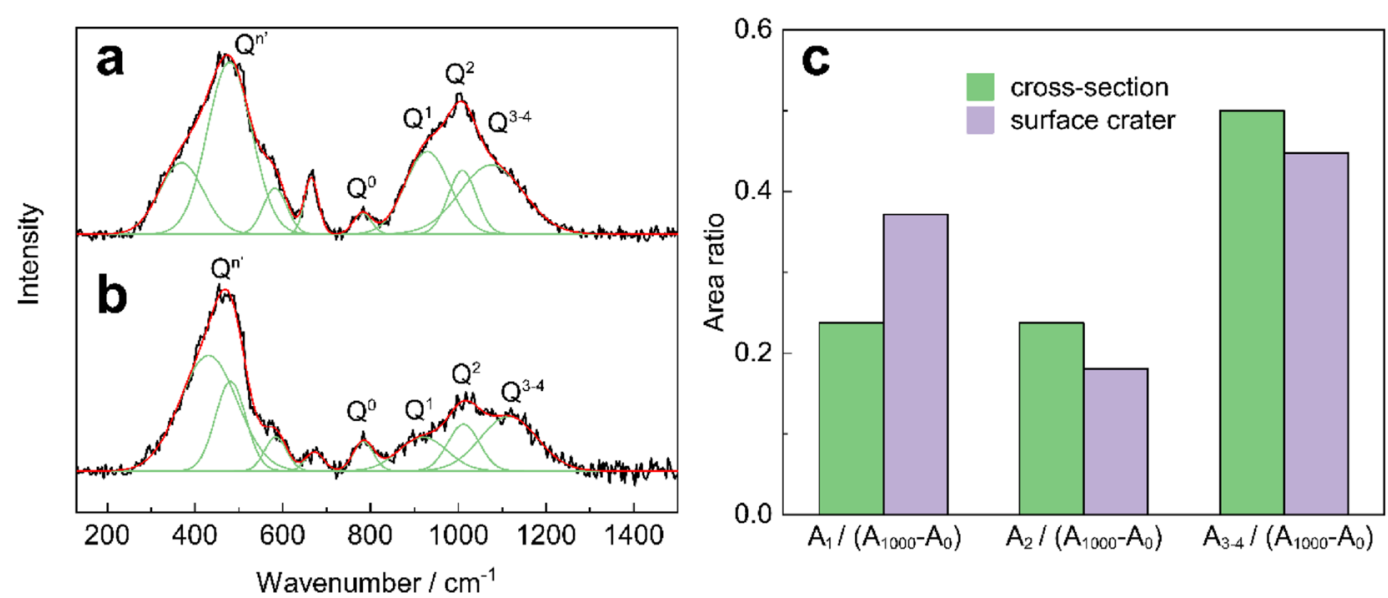

Fig. $\mathbf{6}$ a and $\mathbf{b}$ are the representative Raman spectra of the glass phase recorded at the surface craters and cross-section, respectively; $\mathbf{c}$ the plot of $A_{1} /\left(A_{1000}-A_{0}\right), A_{2} /\left(A_{1000}-A_{0}\right)$, and $A_{3-4} /\left(A_{1000}-A_{0}\right)$ ratios of the stretching envelope of the Raman spectra after baseline subtraction and de-convolutions

Table 5 Raman component wavenumber $\left(Q^{n}\right)$ and area ratios of bending peak over stretching peak $\left(A_{500} / A_{1000}\right)$ and each component in the bending peak $\left(A_{n} /\left(A_{1000}-A_{0}\right)\right)$ of No. 08

\begin{tabular}{lllllll}
\hline Region & $\mathbf{A}_{\mathbf{5 0 0}} / \mathbf{A}_{\mathbf{1 0 0 0}}$ & Parameters & $\mathbf{Q}^{\mathbf{0}}\left(\mathbf{c m}^{-\mathbf{1}}\right)$ & $\mathbf{Q}^{\mathbf{1}}\left(\mathbf{c m}^{-\mathbf{1}}\right)$ & $\mathbf{Q}^{\mathbf{2}}\left(\mathbf{c m}^{-\mathbf{1}}\right)$ & $\mathbf{Q}^{\mathbf{3 - 4}}\left(\mathbf{c m}^{-\mathbf{1}}\right)$ \\
\hline Surface crater & 1.23 & peak position & 782 & 930 & 1009 & 1076 \\
& & $\mathrm{~A}_{\mathrm{n}} /\left(\mathrm{A}_{1000}-\mathrm{A}_{0}\right)$ & - & 0.37 & 0.18 & 0.45 \\
Cross-section & 1.53 & peak position & 784 & 919 & 1012 & 1115 \\
& & $\mathrm{~A}_{\mathrm{n}} /\left(\mathrm{A}_{1000}-\mathrm{A}_{0}\right)$ & - & 0.26 & 0.24 & 0.50 \\
\hline
\end{tabular}

is a corrosion region near the crack, where phase separation structure and many column-like anorthite crystals are found (P1 and P2 in Fig. 7d, EDS analysis results are listed in Table 6). The corrosion morphology is similar to sample No. 08. The morphology of porous structure in the craters near the crack can be clearly seen in the secondary electron SEM image (Fig. 7f). In addition, a few crystals with higher $\mathrm{P}_{2} \mathrm{O}_{5}$ content were also found in the nearby glaze (P3 in Fig. 7d). Figure 7i is a SEM image of a severely corroded area in the glaze, which shows that some yellow substances with lower contrast compared with the glaze are distributed in the pores and cracks of the glaze except for the glaze surface, showing a trend of extending from outside to inside. Figure $7 \mathrm{~g}$ and $\mathrm{h}$ are the OM and SEM images of the corrosion area near a crack. It can be found that the corroded area presenting as yellow (area A) extends along the crack to the inside of the glaze layer. A small number of substances with lower contrast can be found in nearby pores (P4 in Fig. 7h). EDS analysis results show that the $\mathrm{MgO}$ and $\mathrm{Al}_{2} \mathrm{O}_{3}$ contents are very high, reaching $38.91 \mathrm{wt} \%$ and $38.31 \mathrm{wt} \%$, respectively, and the $\mathrm{Fe}_{2} \mathrm{O}_{3}$ content is also high (Table 6). The morphology and composition of the yellow substances will be described in detail in the next chapter.

\section{The morphology and composition of the corrosion products}

To identify the phase components of the yellow area on the surface of No. 09, XRD analysis was applied to examine two different areas (area 09-1 with yellow substances and gray area 09-2) of No. 09. The results show that the main crystal phases in the gray area are anorthite 
and quartz, while diopside, quartz, and quintinite- $3 \mathrm{~T}$ $\left(\mathrm{Mg}_{4} \mathrm{Al}_{2}\left(\mathrm{CO}_{3}\right)(\mathrm{OH})_{12} \cdot 3 \mathrm{H}_{2} \mathrm{O}\right)$ are detected in the yellow area (in Fig. 8).

Figure $9 \mathrm{a}$ is the OM image of the yellow corrosion area on the glaze surface of No. 09 and Fig. $9 \mathrm{~b}$ and c are the magnified SEM images. It can be found that the yellow corrosion area is mainly composed of a large number of nubbly anorthite crystals and the MgO-rich phase with low contrast (EDS analysis results are listed in Table 7). The MgO-rich phase filled the interspaces between the crystals, while the glass phase in the original glaze cannot be observed. In another position (Fig. 9d), many interwoven lamellar substances and a large number of densely spaced long rod-like diopside crystals can be found (Fig. 9e and f). The $\mathrm{SiO}_{2}$ content of the lamellar substances is lower than the glaze, while the $\mathrm{MgO}$ and $\mathrm{Al}_{2} \mathrm{O}_{3}$ contents are very high, reaching $60.98 \mathrm{wt} \%$ and $38.13 \mathrm{wt} \%$, respectively (Table 7). Similar morphology can also be observed in the SEM images of the polished cross-section of the yellow area (Fig. 9g and i). Figure 9i is the SEM image of the interwoven substances in a pore, and its composition has higher $\mathrm{Fe}_{2} \mathrm{O}_{3}$ content, reaching $35.23 \mathrm{wt} \%$ (Table 7), which is different from the corrosion product on the glaze surface. The $\mathrm{MgO} / \mathrm{Al}_{2} \mathrm{O}_{3}$ (molar ratio) of the lamellar substances in sample No. 09, calculated using the EDS results, is approximately 2:1, which is consistent with the composition of the quintinite phase, supporting the XRD results.

\section{Discussion}

\section{Corrosion process of celadon}

The glaze is a thin glass layer covering the ceramic body [28]. Generally, the glaze is considered to be chemically stable and able to resist most environmental erosion except strong acids and alkalis. The chemical composition of traditional Chinese ancient high-temperature glaze mainly includes $\mathrm{SiO}_{2}, \mathrm{Al}_{2} \mathrm{O}_{3}, \mathrm{CaO}, \mathrm{MgO}, \mathrm{K}_{2} \mathrm{O}$, $\mathrm{Na}_{2} \mathrm{O}, \mathrm{Fe}_{2} \mathrm{O}_{3}$, etc., and it can be approximatively represented by $\mathrm{SiO}_{2}-\mathrm{Al}_{2} \mathrm{O}_{3}-\mathrm{CaO}(\mathrm{MgO})-\mathrm{K}_{2} \mathrm{O}\left(\mathrm{Na}_{2} \mathrm{O}\right)$ glass system. Affected by the chemical composition and the external environment, the corrosion mechanism of the glass presents different characteristics. There are usually two reaction processes, including interdiffusion (or ion exchange) and hydrolysis, but the specific kinetics depends on the glass composition, temperature, $\mathrm{pH}$, composition and renewal rate of the solution, and other factors $[29,30]$. In the acidic or neutral conditions, ionexchange (or interdiffusion) between hydrogen-bearing species $\left(\mathrm{H}^{+}\right.$and $\left.\mathrm{H}_{3} \mathrm{O}^{+}\right)$in aqueous solutions and modified ions in glass (such as alkali and alkaline earth metal ions) (Eq. 1 and Eq. 2) leads to selective leaching of glass elements, and a dealkalinised hydrated layer is usually formed on the glass surface $[6,31-35]$. As the $\mathrm{pH}$ value increases $(\mathrm{pH}>9)$, the hydrated glass network gradually dissolves by hydrolysis of ionic covalent bonds ( $\mathrm{Si}-\mathrm{O}-$ $\mathrm{Si}$ ) (Eq. 3), and local condensation reactions of insoluble species can occur to form a gel $[29,36]$. The sea area where the Dalian Island shipwreck is located is close to the mainland, and the average salinity of the seawater is $30.46-31.89 \%$ [19]. The seawater in Fujian, China is a weakly alkaline environment, with a $\mathrm{pH}$ of about 8.2 , and the $\mathrm{pH}$ value of seawater at different depths has little difference [37]. Therefore, seawater can be approximately regarded as a weakly alkaline salt solution containing $\mathrm{Cl}^{-}, \mathrm{Na}^{+}, \mathrm{Mg}^{2+}, \mathrm{SO}_{4}{ }^{2-}, \mathrm{Ca}^{2+}, \mathrm{K}^{+}$, etc. In the corrosion process of celadon glaze, the ion exchange seems to be insignificant, and there is no dealkalinised layer formed on the glaze surface, which may be related to the higher $\mathrm{pH}$ and salinity of seawater. The dissolution process of the glass network may be the main reaction in the corrosion process, and although the ion exchange reaction also occurs at the same time, there is no obvious feature that can be distinguished.

$$
\begin{aligned}
& \equiv \mathrm{Si}-\mathrm{O}-\mathrm{M}_{\text {(glass) }}^{+}+\mathrm{H}_{\text {(aq) }}^{+} \leftrightarrow \equiv \mathrm{Si}-\mathrm{OH}_{\text {(glass) }}+\mathrm{M}^{+} \\
& \equiv \mathrm{Si}-\mathrm{O}-\mathrm{M}_{\text {(glass) }}^{+}+\mathrm{H}_{3} \mathrm{O}_{(\text {aq) }}^{+} \leftrightarrow \\
& \equiv \mathrm{Si}-\mathrm{OH}_{\text {(glass) }}+\mathrm{H}_{2} \mathrm{O}+\mathrm{M}^{+} \\
& \equiv \mathrm{Si}-\mathrm{O}-\mathrm{Si} \equiv+\mathrm{OH}^{-} \rightarrow \equiv \mathrm{Si}-\mathrm{OH}+\equiv \mathrm{Si}-\mathrm{O}^{-}
\end{aligned}
$$

From the perspective of microstructure, however, in addition to the glass phase, there are a certain number of unmelted quartz grains and pores in the ancient glaze. During the firing process of the high-temperature calcium glaze, crystallization, phase-separation, or phase separation-crystallization structure can be formed, which

(See figure on next page.)

Fig. $7 \mathrm{OM}$ and SEM images of sample No. 09, a and b polished cross-section; c-e a corroded region at different magnification, located near a crack at the glaze-body interface in (b), where P1, P2 and P3 in (d) are phase-separation region, short column-like anorthite crystals, and phosphorus-containing crystals, respectively; $\mathbf{f}$ the rectangle region in (e): the porous structure formed after the corrosion of glass phase; $\mathbf{g}$ and $\mathbf{h}$ a corroded area near a crack, where area A is the corroded area presenting as yellow, and area B shows the Mg-rich substances in the pores; $\mathbf{i}$ the rectangle region in (a), and the dashed arrow indicates the corrosion path in the glaze layer. $\mathbf{f}$ is a secondary electron SEM image and the others are backscattered electron SEM images. The marked positions (P1-P4) were examined by EDS and the results were listed in Table 6 

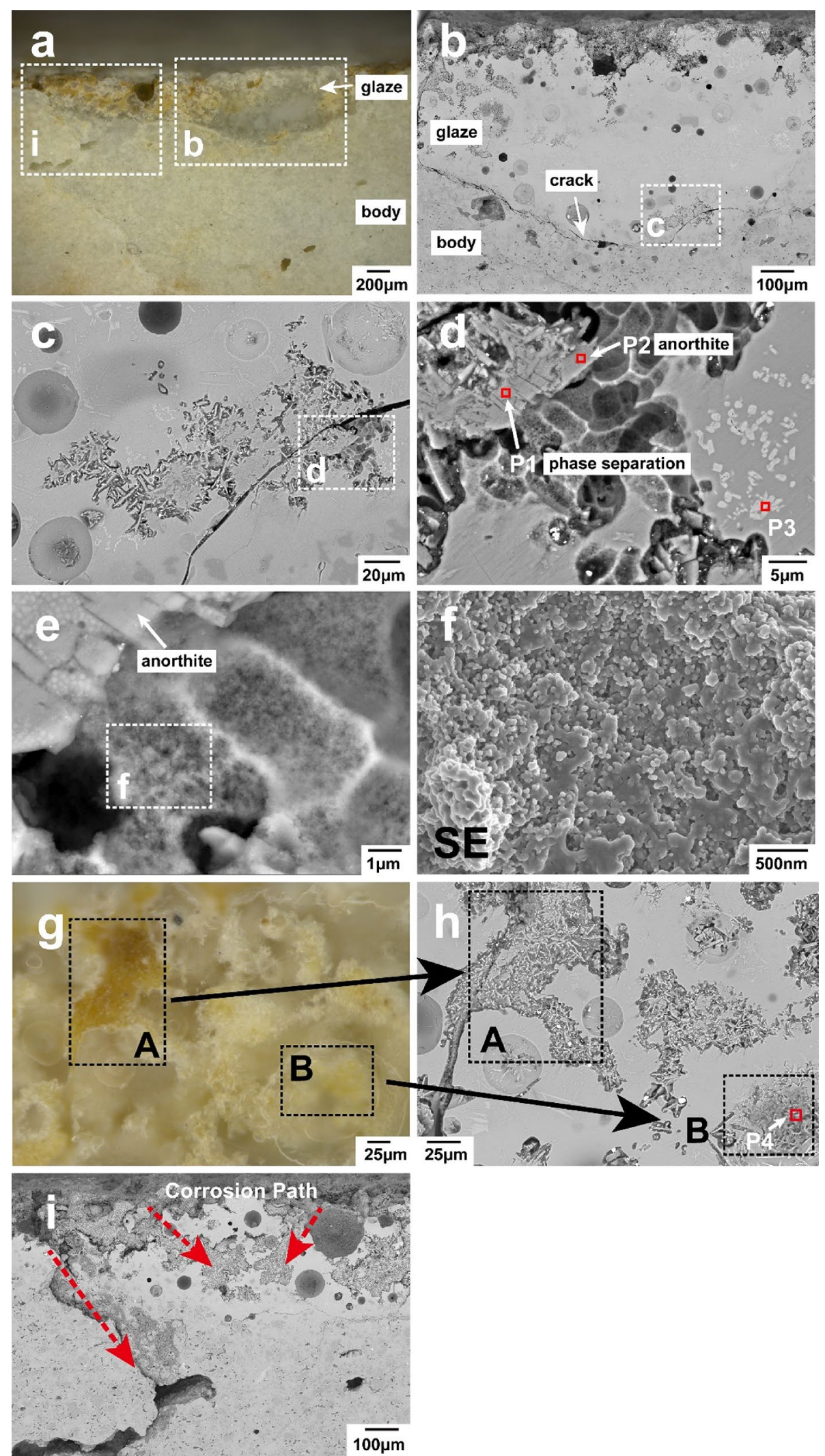

Fig. 7 (See legend on previous page.) 
Table 6 Chemical compositions of the marked positions in Fig. 7d and i (in wt\%)

\begin{tabular}{|c|c|c|c|c|c|c|c|c|c|c|}
\hline Position No. & Ratio & $\mathrm{Na}_{2} \mathrm{O}$ & $\mathrm{MgO}$ & $\mathrm{Al}_{2} \mathrm{O}_{3}$ & $\mathrm{SiO}_{2}$ & $\mathrm{P}_{2} \mathrm{O}_{5}$ & $\mathrm{~K}_{2} \mathrm{O}$ & $\mathrm{CaO}$ & $\mathrm{Fe}_{2} \mathrm{O}_{3}$ & Possible phase \\
\hline \multirow[t]{2}{*}{ P1 } & $w t \%$ & & 3.36 & 14.43 & 62.42 & & 5.53 & 14.25 & & Glass \\
\hline & mol\% & & 5.33 & 8.97 & 65.87 & & 3.72 & 16.11 & & \\
\hline \multirow[t]{2}{*}{ P2 } & wt\% & 1.25 & 2.17 & 26.30 & 47.19 & & 2.26 & 20.83 & & Anorthite \\
\hline & mol\% & 1.33 & 3.59 & 17.04 & 51.91 & & 1.59 & 24.54 & & \\
\hline \multirow[t]{2}{*}{ P3 } & wt $\%$ & & & 3.94 & 13.60 & 32.15 & & 50.31 & & Calcium phosphate \\
\hline & mol\% & & & 2.78 & 16.30 & 64.60 & & 16.31 & & \\
\hline \multirow[t]{2}{*}{ P4 } & wt $\%$ & & 38.91 & 38.31 & 18.27 & & & & 4.51 & Quintinite \\
\hline & mol\% & & 57.88 & 22.35 & 18.09 & & & & 1.68 & \\
\hline
\end{tabular}

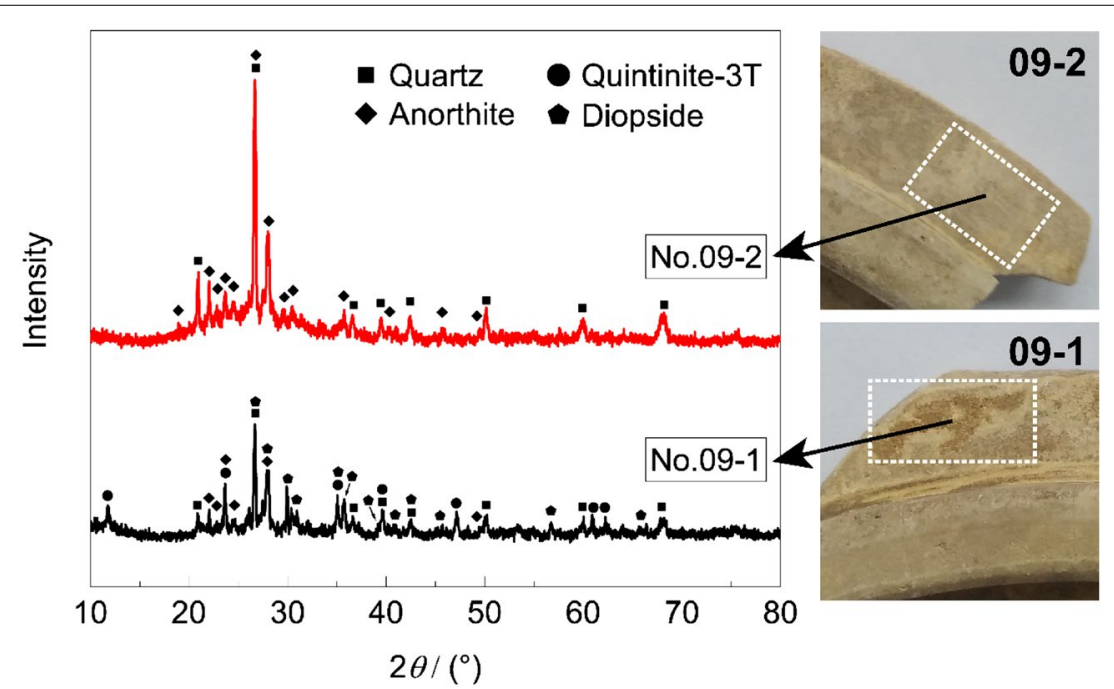

Fig. 8 XRD spectra of glaze surface of No. 09, 09-1 and 09-2 were tested in the area with yellow substances and the gray area with no yellow substances, respectively

depends upon both the chemical composition and the firing schedule. The complex microstructure determines that the corrosion process cannot be considered only from the influence of glaze composition. Previous studies have focused on the corrosion of crystal phases in the glaze. Researchers have evaluated the corrosion resistance of different crystal phases on the glaze surface of commercial floor tiles and sanitary wares in different aqueous solutions $[38,39]$. The study on ancient Jun glazes buried in the soil environment has shown that the wollastonite crystalline phase in the glaze will be preferentially corroded [40].

The chemical stability of the glass is changed to a certain extent because of the phase-separation structure $[41,42]$, in which the composition of each phase and the shape and distribution of the phase-separation structure are important influencing factors [42]. The phase-separation structure in the typical crystalline phase-separated glaze in ancient China is usually accompanied by the crystallization of anorthite, which is different from the relatively uniform phase-separation structure in glass.

(See figure on next page.)

Fig. 9 The morphology of corrosion products in the glaze of No. 09, $\mathbf{a}$ and $\mathbf{b}$ are the OM and SEM images of the yellow area on the glaze surface, respectively; $\mathbf{c}$ the rectangle region in (b); $\mathbf{d}$ the rectangle region $\mathrm{d}$ in (b): a yellow area on the glaze surface; (e) interwoven lamellar substances in a pore; $\mathbf{f}$ the long rod-like diopside crystals near the pore in (e); $\mathbf{g}$ the polished cross-section of the yellow area; $\mathbf{h}$ and $\mathbf{i}$ are the magnified SEM images for (g): interwoven substances in a pore in the glaze layer. The composition of positions P1-P6 were examined by EDS, and the results are listed in Table 7 

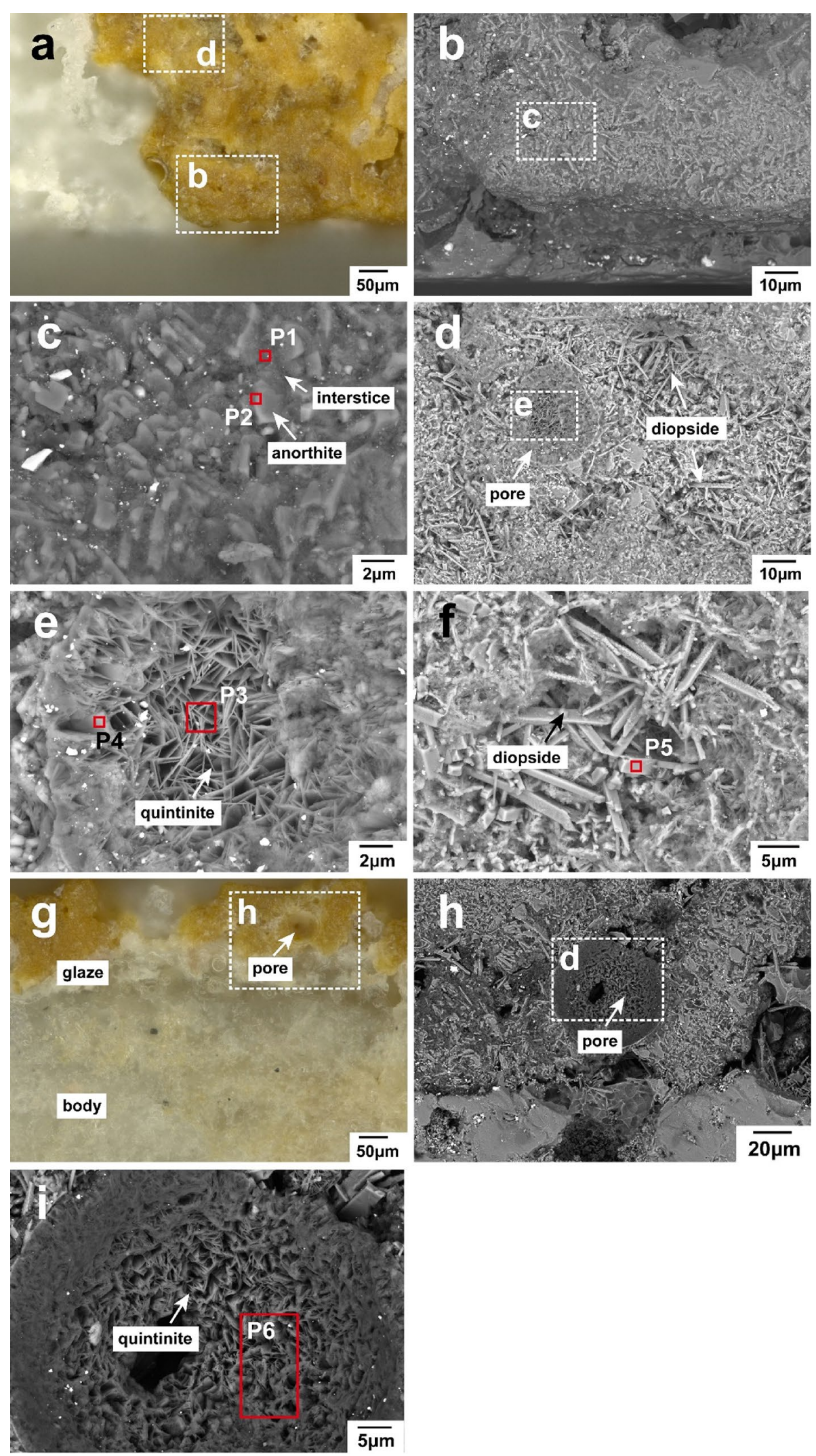

Fig. 9 (See legend on previous page.) 
Table 7 Chemical compositions of the marked positions in Fig. 9c, e, f, and i (in wt\%)

\begin{tabular}{|c|c|c|c|c|c|c|c|c|c|c|}
\hline Position No & Ratio & $\mathrm{Na}_{2} \mathrm{O}$ & $\mathrm{MgO}$ & $\mathrm{Al}_{2} \mathrm{O}_{3}$ & $\mathrm{SiO}_{2}$ & $\mathrm{~K}_{2} \mathrm{O}$ & $\mathrm{CaO}$ & $\mathrm{TiO}_{2}$ & $\mathrm{Fe}_{2} \mathrm{O}_{3}$ & Possible phase \\
\hline \multirow[t]{2}{*}{ P1 } & wt $\%$ & & 34.60 & 30.86 & 21.82 & 2.61 & 2.65 & 4.50 & 2.97 & Quintinite \\
\hline & mol\% & & 51.48 & 18.00 & 21.61 & 1.65 & 2.81 & 3.35 & 1.10 & \\
\hline \multirow[t]{2}{*}{ P2 } & wt $\%$ & 0.30 & 1.97 & 33.94 & 41.04 & & 19.32 & 3.44 & & Anorthite \\
\hline & mol\% & 0.33 & 3.38 & 22.84 & 46.87 & & 23.64 & 2.95 & & \\
\hline \multirow[t]{2}{*}{ P3 } & wt $\%$ & & 60.98 & 38.13 & 0.89 & & & & & Quintinite \\
\hline & mol\% & & 79.69 & 19.54 & 0.77 & & & & & \\
\hline \multirow[t]{2}{*}{ P4 } & wt $\%$ & & 57.94 & 39.65 & 2.41 & & & & & Quintinite \\
\hline & mol\% & & 77.16 & 20.71 & 2.14 & & & & & \\
\hline \multirow[t]{2}{*}{ P5 } & wt $\%$ & & 17.03 & 3.75 & 51.12 & & 27.13 & & 0.97 & Diopside \\
\hline & mol\% & & 23.62 & 2.04 & 47.18 & & 26.83 & & 0.34 & \\
\hline \multirow[t]{2}{*}{ P6 } & wt $\%$ & & 35.11 & 25.12 & 4.54 & & & & 35.23 & Quintinite \\
\hline & mol\% & & 61.82 & 17.35 & 5.32 & & & & 15.51 & \\
\hline
\end{tabular}

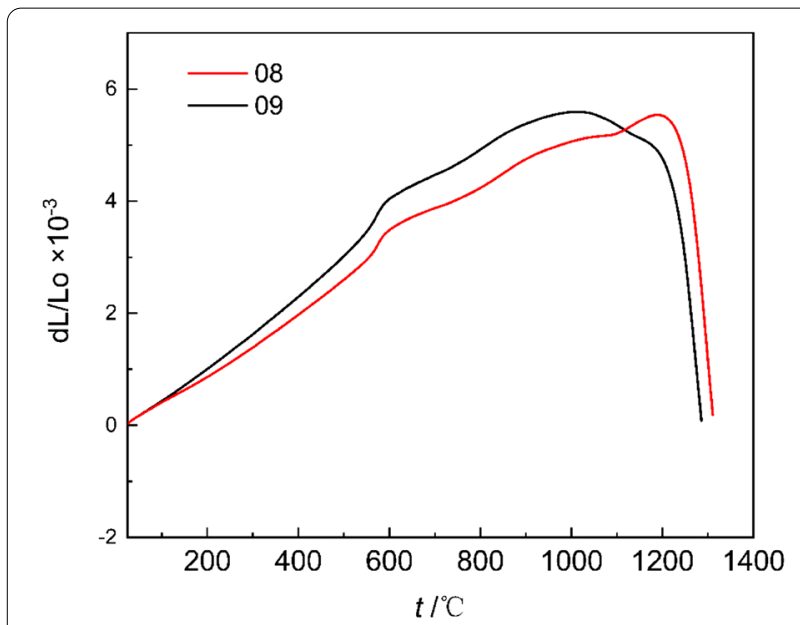

Fig. 10 Thermal expansion curves of Nos. 08 and 09

Three different morphologies of the phase-separation structure are presented due to the inhomogeneity of the glaze composition. When the glass composition is located in the low $\mathrm{CaO}$ content region within the liquid-liquid immiscibility boundary above $950{ }^{\circ} \mathrm{C}$ in the $\mathrm{CaO}-\mathrm{Al}_{2} \mathrm{O}_{3}-\mathrm{SiO}_{2}$ equilibrium phase diagram, the discrete droplet phase should be $\mathrm{CaO}$-rich phase, and the glass matrix is the $\mathrm{SiO}_{2}$-rich phase [43]. At the same time, other network modifiers such as iron ions and magnesium ions also tend to be enriched in the $\mathrm{CaO}$-rich phase with a large number of non-bridging oxygen atoms (NBO).

The tests revealed that the firing temperature of Nos. 08 and 09 are approximately $1215{ }^{\circ} \mathrm{C}$ and $1190{ }^{\circ} \mathrm{C}$, respectively (Fig. 10), which are lower than Longquan celadon wares with proper firing temperature $\left(1220-1280{ }^{\circ} \mathrm{C}[44,45]\right)$. The typical representative is sample No. $06\left(1265^{\circ} \mathrm{C}\right)$ excavated from the same shipwreck. Previously the influence of firing temperature and chemical composition on the microstructure of celadon glaze have been discussed, these celadon glazes with lower firing temperatures and high $\mathrm{MgO}$ content have a special microstructure different from transparent glazes. In addition to many crystals on the glaze surface, there are also a large number of crystals in the glaze layer as a whole, resulting in opaque and matt glaze. In the anorthite crystallization-phase separation structure in the glaze, the CaO-rich droplets with higher contrast are discretely distributed in the $\mathrm{SiO}_{2}$-rich matrix with lower contrast (Figs. 5d and f). Due to the existence of a large number of $\mathrm{NBO}$, the CaO-rich phase has lower corrosion resistance than the $\mathrm{SiO}_{2}$-rich phase. On the other hand, the glass phase near the crystal interface is also more likely to be corroded (Fig. 5f), which may be explained by the less tight arrangement of atoms and more vacancies at the crystal-glass phase interface. At the same time, the interstices created by corrosion at the phase interface provide a channel for external solution to enter the glaze layer, thereby promoting the corrosion process. With the corrosion of the interface layer, the combination of the anorthite crystals and the glass phase is gradually destroyed, which causes the shedding of the local crystals. Combining the previous research on the celadon wares with transparent glaze that is well preserved in the same ship, it can be found that the crystallization-phase separation structure with lower chemical stability does significantly affect the corrosion process in the seawater.

For the glaze with the characteristics of crystallizationphase separation structure and the specific marine buried environment, we propose a possible corrosion process in the form of a schematic diagram, as shown in Fig. 11. First of all, ion exchange occurred between the glaze and seawater, giving rise to the minor alteration of the $\mathrm{Si}-\mathrm{O}-\mathrm{Si}$ network. The long-term reaction may lead to 


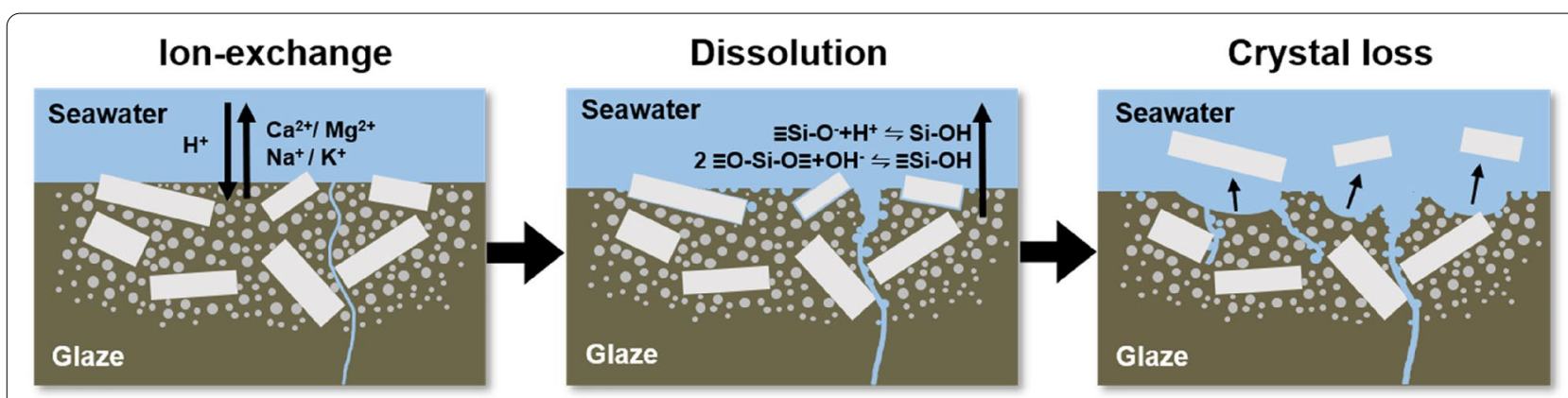

Phase-separated droplets

Watery crack

Fig. 11 Schematic diagram of the corrosion process of crystalline phase-separated structure in the glaze in the marine environment

microcracks because of the network contraction, which increased the surface available for the reaction $[6,8]$. The CaO-rich phase-separated droplets are more likely to react with seawater and the phase-separated droplets were gradually corroded, forming a local porous structure. Secondly, the porous structure, increasing the local specific surface area, which also accelerates the corrosion process of the local $\mathrm{SiO}_{2}$-rich matrix to a certain extent. At the same time, the glass-crystal interface becomes loose and porous due to the corrosion of the phase-separated droplets. Finally, as the hydrolysis of $\mathrm{SiO}_{2}$-rich matrix, the interior $\mathrm{CaO}$-rich phase-separated droplets are gradually exposed. In the process of alternate dissolution of the two separated glass phases, anorthite crystals are also lost and a hole with a size of tens of microns is formed. The above steps are not absolute but change dynamically under different actual conditions.

The corrosion process will continue to change dynamically as the local corrosion environment changes [5]. Finally, different types of the secondary phase precipitated due to the reaction between the released cations from glass and the exogenous anions, or the result of intense hydrolysis-reprecipitation [30, 46]. The large number of corrosion products appearing in the celadon from the Dalian Island shipwreck also reflects the complexity of the marine burial environment and corrosion process. The formation process of corrosion products will be discussed further in the next chapter.

\section{The formation of corrosion products}

The buried environment of celadon wares can be indirectly reflected by the corrosion products in the body and glaze, which is of great significance to deeply understand the influence of the marine environment on the corrosion process. The original appearance of sample No. 09 is significantly changed because of a lot of yellow substances (mainly quintinite phase) on the surface. It is worth noting that the yellow substances with a similar composition was also found in the cracks of sample No. 6. The contents of $\mathrm{MgO}$ and $\mathrm{Fe}_{2} \mathrm{O}_{3}$ (approximately $14 \mathrm{wt} \%$ and $17 \mathrm{wt} \%)$ are much higher than those in the glaze. Therefore, the high $\mathrm{Fe}_{2} \mathrm{O}_{3}$ content may be related to the corrosion of the iron wares carried on the same ship.

Quintinite group minerals are typical layered double hydroxides (LDH), which have a similar structure to brucite. Its chemical formula can be presented as $\left[\left(\mathrm{M}^{2+}{ }_{4} \mathrm{M}^{3+}{ }_{2}\right)(\mathrm{OH})_{12}\right]\left(\mathrm{CO}_{3}\right) \cdot\left(\mathrm{H}_{2} \mathrm{O}\right)_{3}$, where $\mathrm{M}^{2+}$ can be $\mathrm{Mg}^{2+}, \mathrm{Fe}^{2+}, \mathrm{Mn}^{2+}$, and $\mathrm{M}^{3+}$ can be $\mathrm{Al}^{3+}, \mathrm{Fe}^{3+}$ [47-49]. Among them, quintinite belongs to the quintinite group minerals, and the divalent ions and trivalent ions are $\mathrm{Mg}$ and $\mathrm{Al}$, respectively. Because of the extensive solid-solution between the $\mathrm{Mg}$ and $\mathrm{Fe}$ end-members in the quintinite group minerals [47], the various compositions of the lamellar crystals in different pores (Fig. 9e and i) are also related to their formation process.

Since the quintinite phase usually starts to undergo irreversible transformation above $400{ }^{\circ} \mathrm{C}$, decomposing into the periclase and the magnesia-aluminum spinel phase [50-52], which means that the substances are impossibly formed during the firing process of the ceramics. Therefore, the more possibility is that the substance was formed during the long-term alteration of ceramics in seawater. As far as we know, no quintinite phase has been found as a corrosion product in ceramics or glass before. It is worth noting that the quintinite phase is formed during the alkali-activation process of stone wools with high $\mathrm{Mg}$ content (Si-rich amorphous phase) [53], but the $\mathrm{pH}$ value of the solution $(\mathrm{NaOH}$ solution, $6.25 \mathrm{~mol} / \mathrm{L}$ ) is very high. A recent study found that the quintinite phase was detected in the ceramic floor tiles (Akko Tower Wreck, Akko Port, Israel, nineteenth century) in a shipwreck under the sea [54], although its source was not specified and it was not directly observed, 
it is probably also due to the long-term alteration. Therefore, under alkaline conditions, materials containing $\mathrm{Mg}$ and $\mathrm{Al}$ may be transformed into quintinite phases under certain circumstances, although the specific reaction conditions and reaction process still need to be studied.

In our research, during the corrosion process of the crystalline phase-separated structure of No. 09, the corrosion of the phase-separated droplets leads to the appearance of the sub-micron porous structure. These small holes may gradually connect after further corrosion to form porous channels or cracks in the glaze. As seawater enters, a relatively stable micro-environment (relative to the glaze surface contacting with the flowing seawater directly) is formed inside these pores $[7,8]$. The internal corrosive micro-environment has a higher $\mathrm{S} / \mathrm{V}$ value ( $\mathrm{S}=$ exposed surface of glass and $\mathrm{V}=$ volume of solution), and the material exchange with the external seawater is relatively slow, which is conducive to the saturation and precipitation of insoluble salts [55]. During the corrosion process, the $\mathrm{pH}$ value of the local corrosion environment probably increases, providing alkaline conditions, while $\mathrm{Mg}^{2+}$ and $\mathrm{HCO}_{3}{ }^{-}$ions are provided by the seawater, $\mathrm{Al}, \mathrm{Si}$, or $\mathrm{Fe}$ are from the dissolution of the glaze, Eq. 4 may occur under certain conditions to form quintinite crystals.

$$
\begin{aligned}
& 4 \mathrm{Mg}^{2+}+2 \mathrm{Al}^{3+}+\mathrm{HCO}_{3}^{-}+13 \mathrm{OH}^{-}+2 \mathrm{H}_{2} \mathrm{O} \rightarrow \\
& {\left[\left(\mathrm{Mg}_{4} \mathrm{Al}_{2}\right)(\mathrm{OH})_{12}\right]\left(\mathrm{CO}_{3}\right) \cdot 3 \mathrm{H}_{2} \mathrm{O}}
\end{aligned}
$$

The formation process of corrosion products varies in different regions, which may be related to the space for crystal growth. The space is limited in the small holes of the porous structure left by the corrosion of phase-separated droplets, causing the crystals to not develop into good morphology. These corrosion products fill in the porous channels and gradually wrap the nearby anorthite crystals to form a composite corrosion structure. However, the loose and porous structure cannot completely prevent the ingress of seawater, and seawater could also directly enter the interior of the glaze through the cracks, which further intensifies the corrosion process. While the larger pores in the glaze provide a good growth space. After seawater enters and fills the pores, the ions in the solution are gradually saturated with the corrosion process, leading to the formation of a well-developed lamellar structure. In Fig. 7i we have found that defects such as pores and cracks are usually fast corrosion paths in the glaze layer, which provide spaces with different volumes for the formation of corrosion products.
Generally speaking, the corrosion products in the glaze are formed under specific conditions, which are closely related to the marine buried environment and the original glaze composition. The porous structure formed by the corrosion of crystalline phase-separated structure, as well as cracks, pores, and other specific structures in the glaze also play an important role in the formation of corrosion products.

\section{Conclusions}

The two Longquan celadon wares from the Dalian Island shipwreck of the Yuan Dynasty have been buried under the seabed for more than 600 years and corroded severely. This paper analyzed the microstructure and corrosion products of the samples, and the following conclusions are obtained:

1. The severely corroded opaque matte glazes belong to the products with lower firing temperatures in Longquan celadon. They have a special anorthite crystallization-phase separation structure with lower chemical stability, which is an important reason affecting the corrosion process of the glaze in the marine environment.

2. The corrosion process of the glaze with anorthite crystallization-phase separation structure can be roughly divided into three stages, including ion exchange, hydrolysis of silicate glass network, and the shedding of the crystals. The CaO-rich phase-separated droplets and the crystal-glass interface layer are preferentially corroded, forming the porous structure, which accelerates the hydrolysis of the $\mathrm{SiO}_{2}$-rich matrix. Eventually, the anorthite crystals are also lost and a large-sized hole is formed.

3. The corrosion products in the glaze are mainly quintinite group minerals. The formation process is closely related to the corrosion of the celadon and the external marine environment. The porous structure and cracks in the glaze promote the process, and pores provide enough space for crystal growth.

\section{Abbreviations}

CE: Common Era; OM: Optical microscopy; SEM-EDS: Scanning electron microscopy-energy dispersive X-ray spectrometry; XRD: X-ray diffraction; NBO: Non-bridging oxygen atoms. 


\section{Supplementary Information}

The online version contains supplementary material available at https://doi. org/10.1186/s40494-021-00583-4.

Additional file 1: Table S1. Sample list of the all selected celadon shards from the Dalian Island shipwreck of the Yuan Dynasty. Table S2. Summary of the supplemental characterization results.

\section{Acknowledgements}

Not applicable.

\section{Authors' contributions}

WL was responsible for funding acquisition, conceptualization, supervision and writing-review. YH was responsible for investigation, data curation and writing-original draft. CS and XL were responsible for methodology. JL provided the samples to be investigated in this study. All authors read and approved the final manuscript.

\section{Funding}

This work was financially supported by National Key R\&D Program of China (2019YFC1520202), and the Independent Deployment Project of Institute of Deep-Sea Technology Innovation, Chinese Academy of Sciences.

\section{Availability of data and materials}

The datasets used and/or analysed during the current study are available from the corresponding author on reasonable request.

\section{Declarations}

\section{Competing interests}

The authors declare that they have no competing interests.

\section{Author details}

${ }^{1}$ Shanghai Institute of Ceramics, Chinese Academy of Sciences, Shanghai 201899, China. ${ }^{2}$ Key Scientific Research Base of Ancient Ceramics, State Administration for Cultural Heritage, Shanghai 201899, China. ${ }^{3}$ Key Laboratory of the Comprehensive Analysis Technology for Ancient Ceramics and Its Applications, Ministry of Culture and Tourism, Shanghai 201899, China. ${ }^{4}$ University of Chinese Academy of Sciences, Beijing 100049, China. ${ }^{5}$ Fujian Museum, Fuzhou 350025, China.

Received: 17 May 2021 Accepted: 25 August 2021

Published online: 07 September 2021

\section{References}

1. The Chinese Ceramic Society. History of Chinese ceramics. Beijing: Cultural Relics Press; 1982. (in Chinese).

2. Liu W. Trading ceramics in the Song and Yuan Dynasties shown from shipwrecks in the southeast coast of China and Southeast Asia. Arch Cult Relics. 2016;6:65-75 (in Chinese).

3. Meng Y. Review of the discoveries and researches of ancient Chinese exported ceramics in the past 40 years. 2019;4:16-52 (in Chinese). https:// doi.org/10.16674/j.cnki.cn35-1066/u.2019.04.002.

4. Li N. Research on the protection of porcelain excavated from the ocean. Beijing: Science Press; 2016. (in Chinese)

5. Carmona N, García-Heras M, Gil C, Villegas MA. Chemical degradation of glasses under simulated marine medium. Mater Chem Phys. 2005;94:92102. https://doi.org/10.1016/j.matchemphys.2005.04.026.

6. Tournie A, Ricciardi P, Colomban P. Glass corrosion mechanisms: a multiscale analysis. Solid State lon. 2008;179:2142-54. https://doi.org/10. 1016/j.ssi.2008.07.019.

7. Palomar T. Characterization of the alteration processes of historical glasses on the seabed. Mater Chem Phys. 2018;214:391-401. https://doi. org/10.1016/j.matchemphys.2018.04.107.
8. Palomar T, Llorente I. Decay processes of silicate glasses in river and marine aquatic environments. J Non Cryst Solids. 2016;44:920-8. https:// doi.org/10.1016/j.jnoncrysol.2016.07.009.

9. Jang S, Nam B, Park D, Kim H, Lee CH, Yu JE. Desalination characteristics for ceramics excavated from Taean shipwreck, Korea. J Cult Herit. 2013;14:229-37. https://doi.org/10.1016/j.culher.2012.05.006.

10. Unruh J. A revised endpoint for ceramics desalination at the archaeological site of Gordion, Turkey. Stud Conserv. 2001;46:81-92. https://doi.org/ $10.2307 / 1506839$

11. Montana G, Randazzo L, Castiglia A, La Russa MF, La Rocca R, Bellomo S. Different methods for soluble salt removal tested on late-Roman cooking ware from a submarine excavation at the island of Pantelleria (Sicily, Italy). J Cult Herit. 2014;15:403-13. https://doi.org/10.1016/j.culher.2013.07.011.

12. Xi A. Comparative study on desalination technology of ceramic wares excavated from "Nan'ao I." Sci Conserv Archaeol. 2020;32:90-7. https://doi. org/10.16334/j.cnki.cn31-1652/k.2020.01.012 (in Chinese).

13. Zhao J, Luo H. Transport and crystallization of $\mathrm{NaCl}$ solution in porous silicate materials. J Cryst Growth. 2019;519:25-34. https://doi.org/10.1016/j. jerysgro.2019.05.003.

14. Hao X, Zhu T, Xu J, Wang Y, Zhang X. Microscopic study on the concretion of ceramics in the "Nanhai I" shipwreck of China, Southern Song Dynasty (1,127-1,279 A.D.). Microsc Res Tech. 2018;81:486-93. https://doi.org/10. 1002/jemt.23002

15. Du J, Luo W, Li N, Wang C. Characterization of the micro-contaminants from the inner-body of Kraak porcelain excavated from the "Nan'ao I" shipwreck, the South China Sea. Herit Sci. 2019. https://doi.org/10.1186/ s40494-019-0328-0.

16. Hu X. A study on the protection of several porcelain wares excavated from the Huaguangjiao No. 1 shipwreck site in Xisha Islands. Sci Conserv Archaeol. 2013;25:54-64. https://doi.org/10.16334/j.cnki.cn31-1652/k. 2013.04.013 (in Chinese)

17. Li W, Chen Y, Li N, Li B, Luo W. A study on quantitative evaluation of damage in conservation of ceramics from Huaguangjiao I shipwreck with ICP-AES. Spectrosc Spectr Anal. 2015;35:772-6. https://doi.org/10.3964/j. issn.1000-0593(2015)03-0772-05 (in Chinese)

18. Huang H, Yang Q, Wu L. Safety evaluation of micro-nano bubble cleaning for underwater porcelain from Nanhai I shipwreck. Sci Conserv Archaeol. 2017;29:30-7. https://doi.org/10.16334/j.cnki.cn31-1652/k.2017.03.006 (in Chinese)

19. Underwater Archaeological Research Center of National Museum of China, Institute of Cultural Relics and Archaeology of Fujian Museum, Fuzhou Archaeological team. The Yuan Dynasty shipwreck site at Dalian Island. Beijing: Science Press; 2014 (in Chinese).

20. Colomban P. Polymerization degree and Raman identification of ancient glasses used for jewelry, ceramic enamels and mosaics. J Non Cryst Solids. 2003:323:180-7. https://doi.org/10.1016/s0022-3093(03)00303-x.

21. Colomban P, Paulsen $O$. Non-destructive determination of the structure and composition of glazes by Raman spectroscopy. J Am Ceram Soc. 2005:88:390-5. https://doi.org/10.1111/j.1551-2916.2005.00096.x.

22. Tite MS. Determination of the firing temperature of ancient ceramics by measurement of thermal expansion. Nat. 1969;222:81. https://doi.org/10. 1038/222081a0.

23. Tite MS. Determination of the firing temperature of ancient ceramics by measurement of thermal expansion: a reassessment. Archaeometry. 1969;11:131-43. https://doi.org/10.1111/j.1475-4754.1969.tb00636.x.

24. Ma H, Wood N, Doherty C, Zheng J, Zhou G, Duan H. New insights into the calcium flux used in ancient Longquan and Yue kilns based on strontium isotopic compositions. Archaeometry. 2018;61:342-57. https://doi. org/10.1111/arcm.12420.

25. Wang T, Chen P, Wang M, Sang Z, Zhang P, Wang F, et al. Micro-structural study of Yaozhou celadons (Tang to Yuan Dynasty): probing crystalline and glassy phases. J Eur Ceram Soc. 2020;40:4676-83. https://doi.org/10. 1016/j.jeurceramsoc.2020.03.066.

26. Prinsloo LC, Wood N, Loubser M, Verryn SMC, Tiley S. Re-dating of Chinese celadon shards excavated on Mapungubwe Hill, a 13th century Iron Age site in South Africa, using Raman spectroscopy, XRF and XRD. J Raman Spectrosc. 2005;36:806-16. https://doi.org/10.1002/jrs.1367.

27. Colomban P, Etcheverry MP, Asquier M, Bounichou M, Tournié A. Raman identification of ancient stained glasses and their degree of deterioration. J Raman Spectrosc. 2006;37:614-26. https://doi.org/10.1002/jrs.1495. 
28. Colomban P. Glazes and Enamels. In: Richet P, Conradt R, Takada A, Dyon $J$, editors. Encyclopedia of Glass Science, Technology, History, and Culture. Hoboken, New Jersey: Wiley; 2021. p. 1309-26.

29. Lombardo T, Gentaz L, Verney-Carron A, Chabas A, Loisel C, Neff D, et al. Characterisation of complex alteration layers in medieval glasses. Corros Sci. 2013;72:10-9. https://doi.org/10.1016/j.corsci.2013.02.004.

30. Frugier P, Gin S, Minet Y, Chave T, Bonin B, Godon N, et al. SON68 nuclear glass dissolution kinetics: current state of knowledge and basis of the new GRAAL model. J Nucl Mater. 2008;380:8-21. https://doi.org/10. 1016/j.jnucmat.2008.06.044.

31. Douglas RW, El-Shamy TMM. Reactions of glasses with aqueous solutions. J Am Ceram Soc. 1967;50:1-8. https://doi.org/10.1111/j.1151-2916.1967. tb14960.x.

32. Doremus RH. Interdiffusion of hydrogen and alkali ions in a glass surface. J Non Cryst Solids. 1975;19:137-44. https://doi.org/10.1016/00223093(75)90079-4.

33. Advocat T, Crovisier JL, Vernaz E, Ehret G, Charpentier H. Hydrolysis of R7T7 nuclear waste glass in dilute media: mechanisms and rate as a function of Ph. MRS Proc. 2011. https://doi.org/10.1557/proc-212-57.

34. Gong Y, Xu J, Buchanan RC. The aqueous corrosion of nuclear waste glasses revisited: probing the surface and interfacial phenomena. Corros Sci. 2018;143:65-75. https://doi.org/10.1016/j.corsci.2018.08.028.

35. Conradt R. Chemical durability of oxide glasses in aqueous solutions: a review. J Am Ceram Soc. 2008;91:728-35. https://doi.org/10.1111/j.15512916.2007.02101.x.

36. De Ferri L, Lottici PP, Vezzalini G. Characterization of alteration phases on Potash-Lime-Silica glass. Corros Sci. 2014;80:434-41. https://doi.org/10. 1016/j.corsci.2013.11.068.

37. Lei Z. Environment Manual of China Sea. Shanghai: Shanghai Jiao Tong University Press; 1988. (in Chinese).

38. Fröberg L, Hupa L, Hupa M. Corrosion of the crystalline phases of matte glazes in aqueous solutions. J Eur Ceram Soc. 2009;29:7-14. https://doi. org/10.1016/j.jeurceramsoc.2008.04.037.

39. Fröberg L, Kronberg T, Törnblom S, Hupa L. Chemical durability of glazed surfaces. J Eur Ceram Soc. 2007;27:1811-6. https://doi.org/10.1016/j.jeurc eramsoc.2006.04.162.

40. Li Z, Ma Y, Ma Q, Chen J, Song Y. New perspective on Jun glaze corrosion: study on the corrosion of light greenish blue and reddish purple glazes from Juntai Kiln, Yuzhou, Henan China. Herit Sci. 2020. https://doi.org/10. 1186/s40494-019-0346-y.

41. Wang C, Zhou L. Effect of phase separation on weathering of soda-limesilica glasses. J Non Cryst Solids. 1986;80:360-70. https://doi.org/10.1016/ 0022-3093(86)90418-7.

42. Taylor P, Ashmore SD, Owen DG. Chemical durability of some sodium borosilicate glasses improved by phase separation*. J Am Ceram Soc. 1987;70:333-8. https://doi.org/10.1111/j.1151-2916.1987.tb05004.x.

43. Li W, Li J, Deng Z, Wu J, Guo J. Study on Ru ware glaze of the Northern Song dynasty: one of the earliest crystalline-phase separated glazes in ancient China. Ceram Int. 2005;31:487-94. https://doi.org/10.1016/00223093(86)90418-7.

44. Ding Y, Guo Z, Zhai Y, Wu M, Qiu X, Shen Y, et al. The body glazes of the Song-Yuan-Ming Longquan Celadon products and their sintered temperature. Palace Mus J. 2019. https://doi.org/10.16319/j.cnki.0452-7402. 2019.07 .004 (in Chinese).

45. Kerr R, Wood N. Science and Civilisation in China: Chemistry and Chemical Technology Part 12 Ceramic Technology. Cambridge: Cambridge University Press; 2004. p. 250.
46. Aréna H, Godon N, Rébiscoul D, Frugier P, Podor R, Garcès E, et al. Impact of iron and magnesium on glass alteration: characterization of the secondary phases and determination of their solubility constants. Appl Geochem. 2017;82:119-33. https://doi.org/10.1016/j.apgeochem.2017. 04.010.

47. Chao GY, Gault RA. Quintinite-2H, quintinite-3T, charmarite-2H, charmarite- $3 \mathrm{~T}$ and caresite- $3 \mathrm{~T}$, a new group of carbonate minerals related to the hydrotalcite-manasseite group. Can Mineral. 1997;35:1541-9.

48. Mills SJ, Christy AG, Génin JMR, Kameda T, Colombo F. Nomenclature of the hydrotalcite supergroup: natural layered double hydroxides. Mineral Mag. 2012;76:1289-336. https://doi.org/10.1180/minmag.2012.076.5.10

49. Zhitova ES, Krivovichev SV, Yakovenchuk VN, Ivanyuk GY, Pakhomovsky YA, Mikhailova JA. Crystal chemistry of natural layered double hydroxides: 4. Crystal structures and evolution of structural complexity of quintinite polytypes from the Kovdor alkaline-ultrabasic massif, Kola peninsula, Russia. Mineral Mag. 2018;82:329-46. https://doi.org/10.1180/minmag.2017. 081.046.

50. Zhitova ES, Greenwell HC, Krzhizhanovskaya MG, Apperley DC, Pekov IV, Yakovenchuk VN. Thermal evolution of natural layered double hydroxides: insight from quintinite, hydrotalcite, stichtite, and iowaite as reference samples for $\mathrm{Co} 3-$ and $\mathrm{Cl}$ - members of the hydrotalcite supergroup. Miner. 2020. https://doi.org/10.3390/min10110961.

51. Yang W, Kim Y, Liu PKT, Sahimi M, Tsotsis TT. A study by in situ techniques of the thermal evolution of the structure of a Mg-Al-CO3 layered double hydroxide. Chem Eng Sci. 2002;57:2945-53. https://doi.org/10.1016/ s0009-2509(02)00185-9.

52. Bera P, Rajamathi M, Hegde MS, Kamath PV. Thermal behaviour of hydroxides, hydroxysalts and hydrotalcites. Bull Mater Sci. 2000;23:141-5. https:// doi.org/10.1007/bf02706556.

53. Yliniemi J, Walkley B, Provis JL, Kinnunen P, Illikainen M. Nanostructural evolution of alkali-activated mineral wools. Cem Concr Compo. 2020. https://doi.org/10.1016/j.cemconcomp.2019.103472.

54. Inberg A, Ashkenazi D, Feldman Y, Dvir O, Cvikel D. A Tale of Two Tiles: Characterization of Floor Tiles from the Nineteenth-Century Akko Tower Shipwreck (Israel). Coat. 2020;10. doi: https://doi.org/10.3390/coatings10 111091. doi: https://doi.org/10.1016/j.matchemphys.2018.04.107.

55. Verney-Carron A, Gin S, Libourel G. A fractured roman glass block altered for 1800 years in seawater: analogy with nuclear waste glass in a deep geological repository. Geochim Cosmochim Acta. 2008;72:5372-85. https://doi.org/10.1016/j.gca.2008.08.018.

56. RRUFF Project. https://rruff.info/diopside/display=default/R040009. Accessed 1 May 2021

57. RRUFF Project. https://rruff.info/quartz/display=default/R040031. Accessed 1 May 2021.

58. RRUFF Project. http://rruff.info/anorthite/display=default/R040059. Accessed 1 May 2021.

\section{Publisher's Note}

Springer Nature remains neutral with regard to jurisdictional claims in published maps and institutional affiliations.

\section{Submit your manuscript to a SpringerOpen ${ }^{\odot}$ journal and benefit from:}

- Convenient online submission

- Rigorous peer review

- Open access: articles freely available online

- High visibility within the field

- Retaining the copyright to your article

Submit your next manuscript at $\boldsymbol{\nabla}$ springeropen.com 